Vol. 6, No. 2, 2019

https://doi.org/10.23939/eem2019.02.076

UDC 334.012

JEL Classification Gode L32

\author{
A. Kozak, \\ University of Economics in Katowice, Poland, MSc, Ph.D student \\ anna.kozak@edu.uekat.pl \\ ORCID: 0000-0001-8903-444X
}

\title{
THE EFFECTIVENESS OF THE PUBLIC SERVICES CO-PRODUCTION PROCESS - RESULTS OF A SYSTEMATIC LITERATURE REVIEW
}

\begin{abstract}
Nowadays co-production is seen as a valuable route to public service reform and to the planning and delivery of effective public services, which is gaining increasing attention. Despite this our understanding of co-production is limited and we still have a lot to learn about how and why coproduction works (and does not). Therefore there is a need to improve knowledge and ability to use co-production successfully. One of the unclear issues are the conditions under which co-production will most likely be effective and how important is trust in this context. This research gap was accepted as a research problem in the article. The main goal was to find answers to two research questions. First, what factors influence the effectiveness of the coproduction of public services process? Second, what is the place and role of trust among the factors conditioning the effectiveness of the co-production process? The research was carried out using the systematic literature review and then the word cloud technique as a visualization of word frequency in a given text. As a result of the study, six key conditions for the effectiveness of the service co-production process were identified. One of them is trust, which also affects other factors, however, this is not the most important condition of effectiveness among those indicated in the literature.
\end{abstract}

Key words: public management, governance, public services, co-production of public services, effectiveness, trust.

\section{Introduction}

Nowadays the steadily growing importance of services is one of the most important trends, including the public sector (Wolfl, 2005; Cali et al., 2008; Van de Walle \& Scott, 2009; Przywojska, 2014; Denhardt \& Denhard 2015). Currently observed social, political, economic and demographic changes force public organizations to search for the new ways of providing public services (Keating, 2001; Kożuch, 2004; Pollitt \& Bouckaert, 2004; Mandl et al., 2008; Mihaiu et al., 2010; OECD, 2011; Calabro, 2012; Osborne et al., 2016; Lewis \& Fall, 2017; Frączkiewicz-Wronka \& Kozak, 2018). Hence, methods of action suspending the effectiveness of providing public services are sought in order to address the citizens needs and satisfy their growing expectations. More and more often the solution is seen in deep engagement of both service providers and service users (which is fundamental for co-production), public services can be managed more effectively and efficiently and meet users' needs in a better way (Bovaird, 2007; Mangai \& De Vries, 2018; Holmes, 2011; Stewart, 2009). Consequently one of the proposed solutions is striving to create an institutional environment fostering the co-production of public services.

The idea of co-production has been known since the 1970s. The precursors of defining the concept were American political scientists and economists Vincent and Elinor Ostrom. The main thesis they formulated in the book Public goods and public choices. In Alternatives for delivering public services: Toward improved performance (Ostrom \& Ostrom, 1977) was that the collaboration between those who supply a service and those who use a service is essential if most public services are to yield the desired results.

Nowadays co-production is seen as a valuable route to public service reform and to the planning and delivery of effective public services, a response 
to the democratic deficit, a route to active citizenship and active communities, and as a means by which to lever in additional resources to public services delivery (Osborne et al., 2016). Coproduction as a new way of thinking about public services has the potential to deliver a major shift in the way of providing services, in ways that make them much more effective, more efficient, and more sustainable (Boyle \& Harris, 2009).

There is no single definition of co-production. Co-production is defined, among others, as the voluntary or involuntary involvement of public service users in any of the design, management, delivery and/or evaluation of public services (Osborne i in., 2016) or regular, long-term relationships between state agencies and organized groups of citizens, where both make substantial resource contributions (Bovaird, 2007) or the involvement of citizens, customers, consumers and / or social organizations in the production of public services (Alford, 2009). Research in various disciplines of science (political science, economics, sociology, management, public policies) increasingly emphasize the importance of the growing role of citizens and the third sector in providing social services. At the beginning of the 21 st century, along with the spread of the model of public governance that dominated theoretical considerations over the public sector (Hausner, 2008; Osborne, 2010; Pestoff, 2012; Wilkin, 2013; Denhardt \& Denhardt, 2015), and the renewed interest in the participatory role of citizens, co-production became the subject of deep theoretical analysis and popular management practice in the local environment (Alford, 2002; Joshi \& Moore, 2004; Osborne \& Brown, 2005; Brandsen \& Pestoff, 2006; Pestoff et al., 2006; Bovaird, 2007; Mitlin, 2008; Needham, 2008; Meijer, 2012; Pestoff et al., 2012; Jakobsen 2013; Osborne i Strokosch 2013; Poochaoren \& Ting, 2015; Frączkiewicz-Wronka et al., 2016; Osborne et al., 2016; Sicilia et al., 2016; Kozak, 2017). Increased interest in co-production over the last two decades has provided important insights about it, at the same time becoming important challenges for public management (Verusche $i$ in. 2012). Coproduction as a new way of thinking about public services has the potential to deliver a major shift in the way of providing services, in ways that make them much more effective, more efficient, and more sustainable (Boyle \& Harris, 2009).

J. Fledderus (2015) argue that one of the most important contemporary researchers in the phenomenon of co-production, not co-production as such, but the way in which co-production is organized and managed determines its effectiveness. Effectiveness refers in this context to both the effectiveness of services as a result of co-production and the effectiveness of the co-production process the extent to which this objective is achieved.

Effectiveness is understood as a "degree to which something is successful in producing a desired result; success" (Oxford Dictionary of English). Effectiveness relates to getting the right things done (Drucker, 2006). Effectively is the action that causes the intended result (Kotarbiński, 1982). The presented praxeological approach causes that the concept of effectiveness refers only to the concept of action and the concept of effectiveness can not be attributed to things (Zieleniewski, 1978). Effectiveness should therefore be seen as a measure of the success of the action (Kondalkar, 2010). The second important feature of effectiveness is purposefulness. Effectiveness consists in the fact that the measures taken lead in the expected way (not accidentally) to the intended result (Kotarbiński, 1982). The measure of effectiveness is the degree of approach to the goal - the cost is not taken into account (Griffin, 2013). Effective action is therefore the best way to achieve the expected results (Bukłaha, 2012).

Referring the concept of effectiveness to coproduction, co-production will be effective if it will be a deliberate and practical action. Effective coproduction will succeed in bringing the desired results such as creating the public/social value and increasing the quantity, quality and effectiveness of public services (Alford, 2009; Bovaird, 2007; Brandsen \& Pestoff, 2006; Brown \& Osborne, 2013; Calabro, 2012; Cepiku \& Giordano, 2014; Glynos \& Speed, 2012; Jakobsen, 2013; Marschall, 2006; Mitlin, 2008; Moore, 1995; Osborne et al., 2016; Ostrom, 1996; Pestoff, 2011; Radnor et al., 2014; Sorensen \& Trofing, 2011; Tuurnas, 2015;). However, as noted by J. Fledderus (2015), one of 


\section{A. Kozak}

the most important contemporary researchers of the phenomenon of co-production, not coproduction as such, but the way in which coproduction is organized and managed determines its effectiveness. This last statement directs research attention to those aspects that are related to public management, in particular ways to support co-production by local government. Therefore, effectiveness in relation to coproduction appears in two contexts: as its goal and as a condition for its achievement.

Similarly, a two-dimensional problem in the context of co-production is trust, which is indicated both as a condition and effect for the successfully co-production. Trust is an input in building the relationships as part of the service co-production process in the sense that it is one of the basic resources of each relationship. No ongoing relationship can survive without it. It is the output in the sense that effective, joint action in the coproduction relationship strengthens and develops trust between the involved parties - successful cooperation produces a deeper and more successful relationship (Osborne et al., 2010).

Trust is defined as "a bet about the future, uncertain actions of other people" (Sztompka, 2007, 310). It is not only a hope, but also an action based on this bet, making a decision that is risky. Trust, taking into account a number of exceptions and reservations, generally has beneficial effects on social relations (Sztompka, 2007). These relations apply to all areas of social life, and the problem of trust in cooperation is gaining growing interest interest from both practitioners and theoreticians. Many researchers emphasize that trust is an indispensable condition for effective cooperation, whether between individuals or organizations, also in the public sector (Latusek, 2008; McQuaid 2010; Osborne et al., 2010; Latusek \& Cook, 2012; Czernek 2012; Kożuch i Sienkiewicz-Małyjurek 2016; Sześciło 2015), also in relation to the coproduction of public services (Yang, 2006; Pestoff, 2011; Osborne \& Strokosch, 2013; Fledderus et al., 2014; Fledderus, 2015). Trust favors cooperation and strengthens it, and also affects its course and effects (Czernek, 2012) because his presence facilitates social interaction and provides the basis for risk taking (Latusek-Jurczak \& PrystupaRządca, 2014).

The category of trust is a key factor in satisfying public needs effectively, which is also one of the main goals of implementing a co-production of public service model (Kożuch \& SienkiewiczMayjurek, 2016). Therefore trust should be as important to the effectiveness of the co-production process of social services. However, while many coproduction researchers pointed out that the effectiveness and efficiency of public services is the goal and effect of co-production, the issue of the effectiveness of the service co-production process is much less frequently discussed and less explored.

It is not clear, as T. Brandsen and V. Pestoff (2006) argued, under which conditions coproduction will most likely be effective and how important is trust in this context. This research gap was accepted as a research problem in the article. Based on the results of the systematic review of literature and using the world cloud technique, the aim of the article is to find the answer to two questions. First, what factors influence the effectiveness of the co-production of public (including social) services process? Second, what is the place and role of trust among the factors conditioning the effectiveness of the co-production process?

\section{Effectiveness of public services co-production - the state of art}

The issues of effectiveness and trust in the context of co-production of public services are multidimensional and interrelated. In terms of effectiveness, co-production has the potential to increase the quantity, quality and effectiveness of public services. This is determined, however, not by the mere fact of using co-production as a model for designing, providing and/or evaluating services, but by the way in which co-production is organized and managed. Thus, we can talk both about the effectiveness of services as a result of coproduction and about the effectiveness of the coproduction process - the extent to which the goal of effectiveness is achieved. Many researchers draw attention to improving the efficiency and effectiveness of public services as the goal and 
effect of co-production, including E. Ostrom (1996), T. Brandsen and V. Pestoff (2006), D. Mitlin (2008), J. Alford (2009), E. Sorensen and J. Trofing (2011), A. Calabro (2012), J. Glynos and E. Speed (2012), L. Brown and S.P. Osborne (2013), D. Cepiku and F. Giordano (2014), Z. Radnor et al. (2014), S. Tuurnas (2015). The literature analysis carried out so far by the author shows that the problem of the effectiveness of the service co-production process is much less frequently discussed and less explored (cf. Pestoff \& Brandsen, 2009).

The current research in this area, regarding the private sector, include works by M. Etgar (2008) and J.S. Chen et al. (2011). M. Etgar (2008) in the proposed descriptive model of consumer coproduction process (including, among others, coproduction pre-conditions and consumers' motivation to co-produce) draws attention to the efficiency of the co-production strategy (due to the cost-benefit analysis), but does not say anything about its effectiveness. The research by J.S. Chen et al. (2011) suggest that (1) a higher degree of partner matching (the degree to which the business management style and entrepreneurial culture of the partners are similar), (2) partner experience (a combination of knowledge and skills that managers acquire and assimilate to increase their managerial and technical abilities to help partners achieve success), and (3) affective commitment (positive emotional attachment and the degree to which partners are mentally connected), significantly contribute to increasing the effectiveness of coproduction practices. Nevertheless, as mentioned above, these studies concern management and coproduction in the private sector.

In the context of public sector important insights on the effectiveness of co-production are provided by C. Miller and S. Stirling (2004). These authors emphasize the importance of individual and social capital for effective co-production and argue that users with less individual capital (physical and financial resources, health, skills, knowledge) must be supported in order to participate effectively in the co-creation of the service. C. Needham (2008) and S. Parker and J. Heapy (2006) also provide specific factors determining the effectiveness of co- production. First, in order to build effective coproduction relations, it is necessary, at least at the beginning, to move away from the point of service provision and to create forums where officials and citizens can talk about their experience with services, recognize common ground and negotiate service improvements (Needham, 2008). Secondly, the involvement between users and producers must take place as part of the service process and not in abstract consultation exercises. Engaging people in co-production does not take place through consultations or meetings, but must happen at the time of the service and through conversation and dialogue, not just by accident (Parker \& Heapy, 2006). Similarly, K. Sienkiewicz-Małyjurek (2016) notes that: "involvement and structuring will not ensure effective co-production without the ability to cooperate with both public organizations and society" (430). In public organizations, this ability includes core business processes, organizational competences and organizational culture, and on the citizens' side - knowledge, skills and attitudes that enable achieving specific results (Kożuch, 2011).

However, these authors mention factors conditioning the effectiveness of the co-production process "by the way", not making this problem the center of their research, nor verifying them empirically. It is different in the case of studies by T. Bovaird and J. Downe (2008) and T. Brandsen and J. K. Helderman (2012).

The study of T. Brandsen and J.K. Helderman (2012) shows that several of the conditions for designing effective management of common pool resources proposed by E. Ostrom (1990) also apply to co-production. The case study of co-production in housing conducted by these researchers shows that the effectiveness of co-production is influenced by: (1) market structure and related economic dynamics; (2) institutional space; (3) clearly defined boundaries and rules; (4) adaptation of rules to local conditions; (5) enabling the actors involved to participate in decision making; (6) monitoring transparency; (7) social infrastructure for conflict resolving; and (8) unlimited community right to self-organization.

Whereas T. Bovaird and J. Downe (2008), focusing on the practices of government 


\section{A. Kozak}

administration, point out such factors influencing the effectiveness of co-production as: (1) identifying and promoting appropriate mechanisms for public involvement and co-production by the central government; (2) government promotion of examples of co-productions that could be used by local authorities in their area; (3) transformation of old institutions into permanently mobilized deliberative and democratic forms; (4) appreciating the role that users and citizens can play in making decisions; (5) empowering the community and supporting the ability of local officials to understand and respond to social needs; (6) developing new skills of both service users and suppliers; (7) realistic level of social expectations; (8) ensuring equal conditions for all types of organizations competing for the provision of local services; (9) financial aspect.

Notwithstanding, none of the indicated publications address the problem of the role and place of trust among the factors determining the effectiveness of the co-production process of public services, while many authors note that trust is the basis of relationships and a precondition for coproduction (Bovaird, 2007; Brown \& Osborne, 2013; Czernek 2012; McQuaid, 2010; Poochaoren \& Ting, 2015; Panda 2016). Co-production is seen as a special kind of relationship (Joshi \& Moore, 2004; Bovaird, 2007; Meijer, 2011; Pestoff, 2012; Roberts et al., 2012). This relationship is the result of cooperation undertaken by the service provider and users. Regardless of the types of co-production distinguished in literature, it is dependent on the presence of trust in the service relationship, because the co-production process can be risky, uncertain, time consuming and expensive for the organization providing public services (Yang, 2006; Osborne $\&$ Strokosch, 2013). However, there have been few studies directly addressing the problem of trust in the co-production of public services (Yang, 2006; Pestoff, 2011; Osborne \& Strokosch, 2013; Fledderus et al., 2014; Fledderus, 2015).

J. Fledderus (2015) pays special attention to the aspect of trust as a result of co-production. As he notes, it is believed that co-production - the involvement of clients in the provision of public services - strengthens trust. However, research on this subject is insufficient to prove what is currently only a supposition (Fledderus et al., 2014). The results of his research indicate that trust in the service provider, local authorities and general trust have significantly decreased among the surveyed co-production participants. Hence, J. Fledderus concludes that not the mere the public service coproduction is important for the increase of trust, but the way in which co-production is organized and managed (Fledderus 2015). However, J. Fledderus's research is one of the few in this area and raises the only one side of the problem - trust as a result, not referring to trust as a condition for the launch and effectiveness of co-production. Hence in this article an answer to the question about the place of trust among factors conditioning the effectiveness of public service co-production was sought.

\section{Research methodology and findings}

In order to identified the factors influence the effectiveness of the co-production process in public sector and the role of trust among theme, the systematic literature review and the word cloud technique have been applied. The systematic literature review is based on establishing facts as a result of secondary data analysis. As a research strategy, it allows to, among others: (1) maintain the objectivity of the analysis, (2) cover the entire research area, (3) properly select sources for further research and (4) consolidate information from many sources (Colicchia \& Strozzi, 2012; SienkiewiczMałyjurek, 2016). The word cloud technique allows to visualize the word frequency in a given text. The frequency of words appears reflects their size in the cloud. The use of this technique makes it possible to illustrate the most important components of the texts analyzed, and its quantitative nature deprives it of the disadvantages of interpretive studies (Tranfield et al., 2003; Klimas \& Czakon, 2010). In the research the software available on the website http://www.wordle.net was used (Steele \& Iliinsky, 2010).

The strategy for the systematic literature review - conducted in July 2019 - involved several steps (Table 1). An electronic search was carried out in the Ebsco, Sciene Direct, Emerald Insight, ProQuest, Scopus and Web of Science databases. 
Table 1.

The systematic literature review strategy

\begin{tabular}{|c|c|c|c|c|c|c|c|}
\hline \multirow[b]{2}{*}{ Stage } & \multirow{2}{*}{ Selection criteria } & \multicolumn{6}{|c|}{ Number of records } \\
\hline & & Ebsco & $\begin{array}{l}\text { Science } \\
\text { Direct }\end{array}$ & Emerald & $\begin{array}{c}\text { Pro } \\
\text { Quest }\end{array}$ & Scopus & $\begin{array}{l}\text { Web of } \\
\text { Science }\end{array}$ \\
\hline 1 & $\begin{array}{l}\text { co-production in title OR abstract OR } \\
\text { key words }\end{array}$ & 9287 & 1754 & 2401 & 3777 & 6771 & 6645 \\
\hline 2 & $\begin{array}{l}\text { co-production of services in title OR } \\
\text { abstract OR key words }\end{array}$ & 561 & 115 & 2197 & 564 & 1170 & 1036 \\
\hline 3 & $\begin{array}{l}\text { co-production AND public services } \\
\text { OR co-production AND social services } \\
\text { in title OR abstract OR key words }\end{array}$ & 70 & 32 & 169 & 80 & 240 & 193 \\
\hline 4 & $\begin{array}{l}\text { papers written in English and } \\
\text { published in peer-reviewed journals }\end{array}$ & 61 & 26 & 60 & 57 & 103 & 149 \\
\hline 5 & $\begin{array}{l}\text { the subject areas of management } \\
\text { science and operations, public } \\
\text { management and administration, } \\
\text { public and social policy }\end{array}$ & 55 & 11 & 27 & 57 & 100 & 115 \\
\hline 6 & elimination of duplicate publications & \multicolumn{6}{|c|}{187} \\
\hline 7 & $\begin{array}{l}\text { verification of abstracts due to co- } \\
\text { production as a leading subject of } \\
\text { research }\end{array}$ & \multicolumn{6}{|c|}{134} \\
\hline
\end{tabular}

First, publications including the word "coproduction" in title or abstract or key words were sought (Stage 1). Then the results were limited to "co-production of services" (Stage 2) and next to the words "co-production" and "public services" or «coproduction" and "social services" in title or abstract or key words (Stage 3). The formulations "coproduction of public services" and "co-production social services" were not applied because they are rarely used even in the most important coproduction publications. Afterwards the search was restricted to the papers that were written in English, published in peer-reviewed journals (Stage 4), and in the subject areas of management science and operations, public management and administration, public and social policy (Stage 5). In this way a total of 365 articles was identified. The duplicate publications have been eliminated from the sample, which reduced the number of articles to 187 (Stage 6 ). The last step was verification of abstracts due to co-production as a leading subject of research (Sage 7). This process reduced the sample to 134 articles form 1998 to 2019 (actually the period of renewed, increased interest in co-production) that have been further analyzed.

The selected articles were analyzed in terms of the occurrence of factors conditioning the effectiveness of the co-production process proposed by the author. Analysis of selected articles led to the observation that as often as the term "effective" as the term "success" is used, hence the analysis has been expanded to these two concepts (which is in line with the definition of effectiveness presented above). The result of this analysis was distinction of 45 papers and 83 factors transcribed by bringing them to key words. The number of factors decreased to 30 after removal of those that appeared only once.

The factors that influence the effectiveness of the co-production of public services process are 


\section{A. Kozak}

(in alphabetical order): active professionals and users engagement, building relational capital among the stakeholders, capability of professionals and users to co-produce, clear communication of the values by the organization, finding a balance between private value and public valued, internal efficacy, involvement of third sector organizations, organizational culture and support, participation of the citizens, reciprocity, relationships between users and professionals, sense of shared responsibility for the provision of a new service, social capital, structure of political institutions, structure of political institutions, suitable ways to motivate the users, trust, type of the service, understanding and responding to the users' needs, users' motivation to co-produce, willingness of professionals and users to make the contribution.

Afterwards those identified factors was quantitatively analyzed using the word cloud technique (Figure 1). As a result 6 factors were identified as the most important for the effectiveness of the service co-production process due to the the frequency of appearance (Table 2). Four of these key factors are on the side of users, one on the side of professionals and one is common.

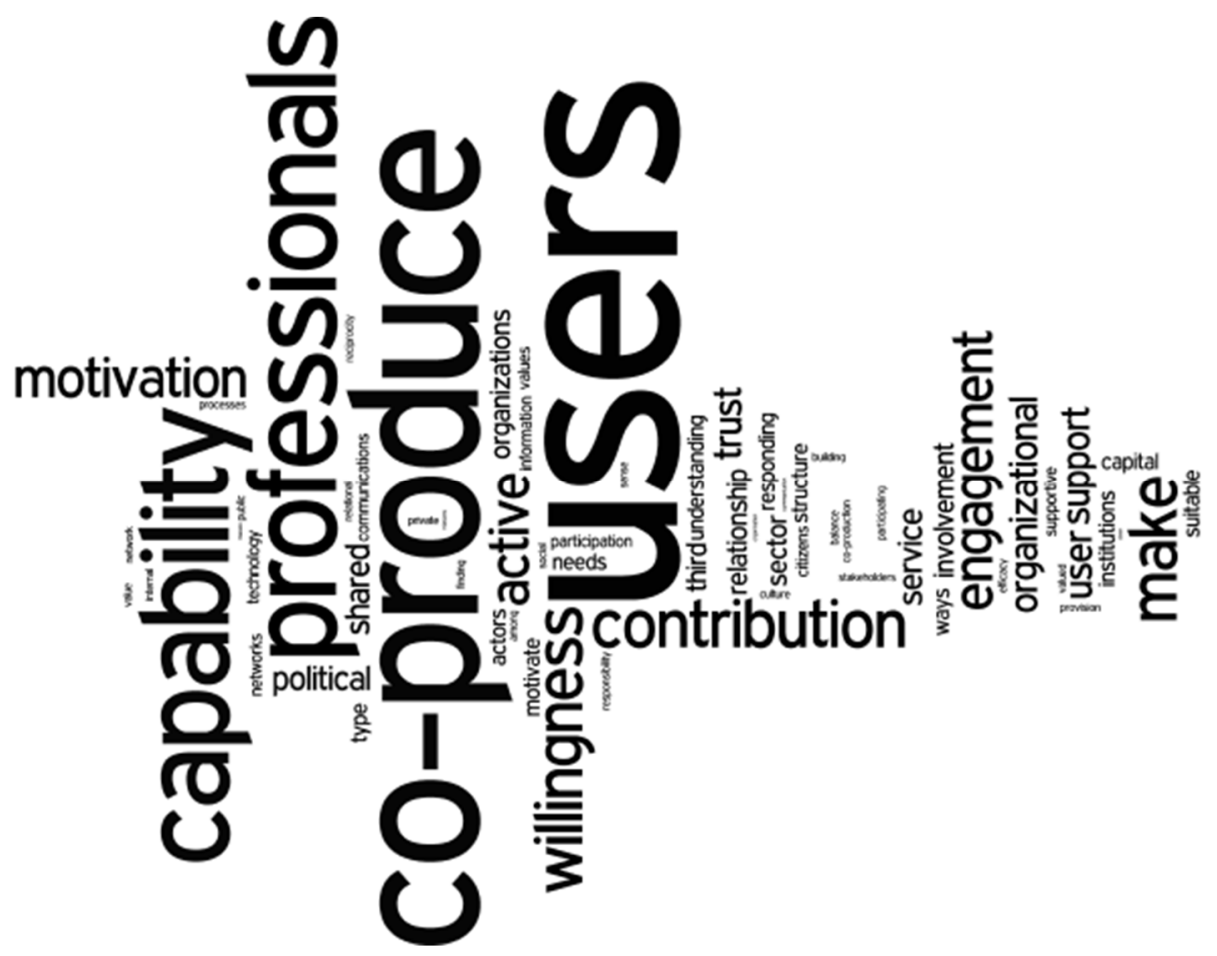

Fig. 1. Factors influencing the effectiveness of the co-production process

Source: developed using wordle.net.

Table 2

The key factors of the effectiveness of public services co-production process

\begin{tabular}{|c|l|l|}
\hline \multicolumn{1}{|c|}{ Side } & \multicolumn{1}{|c|}{ Factors } & \multicolumn{1}{c|}{ Description } \\
\hline $\mathbf{1}$ & \multicolumn{1}{|c|}{$\mathbf{2}$} \\
\hline Users & $\begin{array}{l}\text { Capability of the users to } \\
\text { co-produce }\end{array}$ & $\begin{array}{l}\text { users' skills, education and experience, competencies, resources, } \\
\text { knowledge about their role in the co-production and having something } \\
\text { valuable to contribute }\end{array}$ \\
\hline Professionals & $\begin{array}{l}\text { Capability of the } \\
\text { professionals to co-produce }\end{array}$ & $\begin{array}{l}\text { professionals skills, education and experience, competencies, } \\
\text { substantial/adequate resources and having something valuable to contribute }\end{array}$ \\
\hline
\end{tabular}


Continuation of the table 2

\begin{tabular}{|l|l|l|}
\hline \multicolumn{1}{|c|}{$\mathbf{1}$} & \multicolumn{1}{|c|}{$\mathbf{2}$} \\
\hline Users & $\begin{array}{l}\text { Willingness of the users to } \\
\text { make the contribution }\end{array}$ & $\begin{array}{l}\text { lhe likeliness to consider active engagement and weigh up the } \\
\text { investments of resources (time, money, efforts, experience etc.); }\end{array}$ \\
\hline Users & $\begin{array}{l}\text { Users' motivation to co- } \\
\text { produce }\end{array}$ & $\begin{array}{l}\text { people are benefit maximizers who will only co-produce when } \\
\text { benefits (material, extrinsic reward or intrinsic values) outweigh costs }\end{array}$ \\
\hline Users & Active user engagement & $\begin{array}{l}\text { users are not only passive recipients of public services, but their } \\
\text { commitment is necessary in the interactive relationship between them } \\
\text { and service professionals in the co-production process }\end{array}$ \\
\hline Both & Trust & $\begin{array}{l}\text { mutual relationships in which both parties ate interdependent and take } \\
\text { risks }\end{array}$ \\
\hline
\end{tabular}

The analysis indicates that the capability of the users to co-produce is the most important factor of the effectiveness of co-production (appeared 12 times). The capability of the professionals to coproduce is a similarly important factor which appeared 10 times in the analyzed records. The capability to co-produce means skills (Loeffler \& Bovaird, 2016; Matei, 2016; Paskaleva \& Cooper, 2018; Wiewiora et al., 2015; Verschuere et al., 2012), having something valuable to contribute (Loeffler \& Bovaird, 2016; Sicilia et al.,2016), education and experience (Cepiku \& Giordano, 2014) as well as competencies (Sicilia et al., 2016) of both citizens and service professionals engage in co-production. It is also include citizens' resources (Gao 2017; Sicilia et al. 2019) and knowledge about their role in the co-production (Lino et al., 2019; Loeffler \& Bovaird, 2016; Matei, 2016; Sicilia et al., 2019). The substantial/adequate resources also affect professionals' ability to co-produce (Cepiku \& Giordano, 2014; Fledderus 2015). As Sicilia et al. (2019) pointed out, public managers can increase users' capability and "help them be more effective in the co-production process by providing them with relevant information and basic resources" (p. 8). Equally, however, professionals need to be supported by the organization by providing them, among others, adequate autonomy and substantial resources (Palumbo, 2006).

The third factor because of the frequency of appear is willingness of the users to make the contribution (appeared 10 times). Both professionals and users must be willing to invest their resources (time, money, efforts, experience etc.) in the co- production (Verschuere et al., 2012) but analysis indicates that willingness is more important on the citizens' side (Alford, 2016; Bovaird \& Loeffler, 2016; Farooqi, 2015; Fledderus et al., 2015; Fleming \& Osborne, 2019; Lino et al., 2019; Palumbo, 2016; Van Eijk, 2014; Van Eijk et al., 2017). The willingness of the users to contribute depends on motivation (Alford, 2016), relevance of the topic "only when citizens argue a topic 'salient enough' they will have a willingness to consider active engagement and weigh up the investments of efforts" (Van Eijk, 2014, p. 361), compliance of user values with the values of members of a public organization (Fledderus et al., 2015) and trust in government (Van Eijk, 2014; Van Eijk et al., 2017). The relationship between people's willingness to coproduce and individual characteristics (age, gender, socio-economic status, social connectedness of people etc.) is not clear (Van Eijk et al., 2017). Furthermore, as T. Bovaird and E. Loeffler (2016, p. 268) pointed out, "co-production demands more than willingness, but also relevant knowledge about the co-production task" confirming the significance of the first identified factor and indicates that those factors are interdependent.

Next factor is the users' motivation to coproduce (appeared 8 times). The motivation of the users is considered critical for the effectiveness and sustainability of co-production initiatives (Boccacin, 2017; Farooqi, 2015; Fledderus, 2015; Gao, 2017; Lember et al., 2019; Lino et al., 2019; Van Eijk and Steen, 2014; Verschuere et al., 2012). Similar to willingness, "individual motivations are necessary, but not sufficient, for the success of co- 


\section{A. Kozak}

production" (Lino et al., 2019, p. 287) and users may need sufficient information about their role in the co-production arrangements (Lino et al., 2019) and some skills in addition to their motivation to coproduce (Verschuere et al., 2012). Moreover, related to the aspect of motivation is trust. Fledderus (2015) argued that "more users have trust in the service provider and/or government, the more likely they will cooperate" (p. 554).

The active user engagement is fifth factor with 7 appearances. The determining cause of success of co-production lies not only on the service provider but the people as well. As a result, the role of users once put as only receivers to public services is now seen as the main factor leading to coproduction success (Dhirathiti, 2018; Farooqi, 2015; Fledderus, 2015; Lino et al., 2019; Phillips \& Morgan, 2014; Poocharoen \& Ting, 2015; Thijssen $\&$ van Dooren, 2016). The active engagement of users is required for co-production success because «co-production establishes an interactive relationship between citizens and public service providers (Thijssen \& van Dooren, 2016, p. 88). To encompass the active engagement of citizens, coproduction values have to be present and constantly reinforced (Lino et al., 2019).

Last but one is trust (appeared 7 times) and there is no distinction between users and professionals. Mutual trust is the currency that turns co-production relationships into a success (Boccacin, 2017; Bovaird, 2007; Ewert \& Evers, 2014; Fledderus, 2015; Fledderus et al., 2015; Granier \& Kudo, 2016; Van Eijk \& Steen, 2016; Verschuere, et al. 2012). Trust becomes an important factor because cooperation is the precondition for successful co-production (Fledderus et al., 2015). Bovaird (2007) argued that «co-production means that service users and professionals must develop mutual relationships in which both parties take risks - the service user has to trust professional advice and support, but the professional has to be prepared to trust the decisions and behaviors of service users and the communities in which they live rather than dictate them" (856). Moreover "trust can not only be treated as a dependent variable, but also as an independent variable" (Fledderus, 2015, 554). The more users have trust in the professionals, the more likely they will cooperate but on the other hand trust is higher among co-producers than those who do not coproduce (Fledderus, 2015). Consideration about the role of trust in co-production process are still dominated by the work of J. Fledderus and his coresearches. Few other authors take a closer look at this issue, although they recognize the importance of trust in ensuring the effectiveness of the coproduction process. Presence of trust has a positive effect on users' motivation to co-produce (Fledderus, 2015) and their willingness to contribute in the co-production process (Van Eijk, 2014; Van Eijk et al., 2017). Nevertheless, these conditions, right behind the capability of users and professionals to co-produce, are considered as more important for effectiveness of co-production process than trust.

\section{Conclusions}

Despite increased attention, understanding of co-production is limited and we still have a lot to learn about how and why coproduction works (and does not). Therefore there is a need to to improve knowledge and ability to use co-production successfully (Parrado et al., 2013; Sicilia et al., 2019). Additionally, according to J. Fledderus and M. Honingh, 2016, it is very difficult to design accessible and successful co-produced services. Already in the 1980s, shortly after the concept of coproduction appeared, «recognizing the difficulty of constituting effective institutions to address the challenges associated with coordinating coproduction" L. L. Kiser (1984) came to the «disturbing conclusion that co-production is not likely to be a popular activity" (p. 506). Despite this prognosis, co-production has continued to be a significant aspect of public service provision and management, demanding attention to the specific factors that favor or constrain it in practice (Musso et al., 2018). After several decades of actual lack of much interest in the participatory role of citizens in public (and social) service production, the renewed interest in the public service co-production took place at the beginning of the 21 st century when theoretical considerations and interests of practitioners in the public sector have been dominated by governance model. Therefore, this period was selected for analysis. As a result of a systematic literature review 134 articles published between 1998 and 2019 were identified. These are articles only from the areas of (1) management science and operations, (2) public 
management and administration and (3) public and social policy, in which the main research problem is the co-production of public or social services.

The selected articles were analyzed in terms of the occurrence of the factors of the effectiveness which provided answers to the first research questions - what factors influence the effectiveness of the co-production of public services process? One of the identified factors was trust. Then those factors was quantitatively analyzed using the word cloud technique which resulted in the identification of six key factors for the effectiveness of co-production: (1) the capability of the users to co-produce, (2) the capability of the professionals to co-produce, (3) willingness of the users to make the contribution, (4) users' motivation to co-produce, (5) active user engagement, and (6) trust. This analysis allowed placing trust among the conditions of the effectiveness of co-production process and addressing second research question. Trust, if present, is one of the factors that positively affects effectiveness of public service co-production process. In this respect, coproduction is like cooperation, and trust favors and strengthens it, and also affects its course and effects because his presence facilitates social interaction and provides the basis for risk taking. It is the sixth of the identified factors due to the frequency of appearance, but affects other important factors users' motivation to co-produce and their willingness to co-produce.

The identified factors require empirical testing in specific contexts because, as T. Bovaird, E. Loffler and S. Parrado-Diez $(2002,414)$ argue, "in each country, the approach which is most likely to be effective in activating civil society will depend on its existing characteristics [...] and the specific economic, social and political circumstances of that country". The type of service and type of organization providing it are equally important and and should be included in the analysis. Only then will we be able to say that we know what factors influence the effectiveness of co-production and how we can shape them, but this knowledge will only apply to a very narrow fragment of reality.

\section{References}

1. Alford, J. (2002). Why do public-sector clients coproduce? Toward a Contingency Theory. Administration \& Society, 34(1), 32-56.
2. Alford, J. (2009). Engaging public sector clients: From service-delivery to co-production. Palgrave Macmillan.

3. Alford, J. (2015). Co-Production, Interdependence and Publicness: Extending public service-dominant logic. Public Management Review, 18(5), 673-691. doi: 10.1080/14719037.2015.1111659

4. Boyle, D., Harris, M. (2009). The challenge of coproduction: how equal partnerships between professionals and the public are crucial to improving public services. Discussion paper, NESTA. Retrieved from www.nesta.org.uk/publications/ challenge-co-production

5. Bovaird, T., Loffler, E., Parrado-Diez, S. (2002). Finding a bowling partner: The role of stakeholders in activating civil society in Germany, Spain and the United Kingdom. Public Management Review, 4(3),411-431.

6. Bovaird, T. (2007). Beyond engagement and participation: User and community coproduction of public services. Public Administration Review, 67(5), 846-860.

7. Brandsen, T., Pestoff, V. (2006). Co-production, the third sector and the delivery of public services. An introduction. Public Management Review, 8(4), 493-501.

8. Brown, L., Osborne, S.P. (2013). Risk and Innovation. Towards a Framework for risk governance in public services. Public Management Review, 15(2).

9. Buklaha, E. (2012). Sukces, skuteczność i efektywność $w$ zarzadzaniu projektami, Studia i prace Kolegium Zarzadzania i Finansów, 113, 24-35.

10. Calabro A. (2012). Co-production: An alternative to the partial privatization processes in Italy and Norway. In V. Pestoff, T. Brandsen, B. Verschuere (Eds.), New public governance, the third sector and co-production (pp. 317-360), New York: Routledge.

11. Cali, M., Ellis, K., te Velde, D. W. (2008). The Contribution of Services to Development and the Role of Trade Liberalisation and Regulation. Working Paper 298. Overseas Development Institute.

12. Cepiku, D., Giordano, F. (2014). Co-production in developing countries. Insights fro the community health workers experience. Public Management Review, 16(3), 317-340.

13. Colicchia, C., Strozzi, F. (2012). Supply chain risk management: a new methodology for a systematic literature review. Supply Chain Management: An International Journal, 17(4), 403-418.

14. Czernek, K. (2012), Rola zaufania we wspótpracy na rzecz rozwoju turystyki - przyktad wybranych gmin miejskich Beskidu Ślaskiego. In T. Żabińska (ed.), 


\section{A. Kozak}

Turystyka na obszarach miejskich. Uwarunkowania rozwoju, narzędzia promocji, Studia Ekonomiczne. Zeszyty Wydziałowe Uniwersytetu Ekonomicznego w Katowicach.

15. Denhardt, J. V., Denhard, R. B. (2015). The New Public Service. Serving, Not Steering. New York: Routledge.

16. Drucker, P. F. (2006). The Effective Executive: The Definitive Guide to Getting the Right Things Done. New York: Collins.

17. Fledderus, J., Brandsen, T., Honingh, M. (2014). Restoring turst through the co-production of public services. A theoretical elaboration. Public Management Review, 16(3).

18. Fledderus J., (2015). Building trust through public service co-production. International Journal of Public Sector Management, 28(7), 550-565.

19. Fledderus J., Honingh M. (2016), Why people coproduce within activation services: the necessity of motivations and trust - an investigation of selection biases in a municipal activation program in the Netherlands. International Review of Administrative Sciences, 82(1), 69-87.

20. Fraczkiewicz-Wronka, A., Dobrowolska, M., Arando, S., Wronka-Pośpiech, M., Tkacz, M. (2016). Koprodukcja jako warunek efektywnej deinstytucjanalizacji usług społecznych. Humanum. Międzynarodowe Studia Spoteczno-Humanistyczne, 20(1), 67-78.

21. Fraczkiewicz-Wronka, A., Kozak, A. (2018). Identyfikacja czynników sprzyjających powstaniu koprodukcji $w$ kreowaniu ustug społecznych $w$ środowisku lokalnym - perspektywa Rad Seniorów, Polityka Społeczna, 529(4), 10-17.

22. Gao, X. (2017). Networked Co-Production of 311 Services: Investigating the Use of Twitter in Five U.S. Cities. International Journal of Public Administration, 41(9), 712-724. doi: 10.1080/ 01900692.2017 .1298126

23. Glynos, J., Speed, E. (2012). Varieties of coproduction in public services: time banks in a UK health policy context. Critical Policy Studies, 6(4), 402-433.

24. Griffin, R. W. (2013). Podstawy zarzadzania organizacjami. Warszawa: Wydawnictwo Naukowe $P W N$.

25. Husner, J. (2008). Zarzadzanie publiczne. Warszawa: Wydawnictwo Naukowe Scholar.

26. Holmes, B. (2011), Citizens' engagement in policymaking and the design of public services, Research Paper No. 1 (2011-2012). Politics and Public Administration Section, Parliament of Australia, Retrieved from: www.aph.gov.au/ About_Parliament/Parliamentary_Departments/Pa rliamentary_ Library/pubs/rp/rp1112/12rp01 (accessed 12 September 2019).

27. Jakobsen, M. (2013). Can Government Initiatives Increase Citizen Coproduction? Results of a Randomized Field Experiment. Journal of Public Administration Research and Theory, 23(1), 27-54.

28. Joshi, A., Moore, M. (2004). Institutionalised coproduction: Unorthodox public service delivery in challenging environments. Journal of Development Studies, 40(4), 31-49.

29. Keating, M. (2001). Public Management Reform and Economic and Social Development. OECD Journal on Budgeting, 1/2, 141-212.

30. Kiser, L. L. (1984). Toward an Institutional Theory of Citizen Coproduction. Urban Affairs Quarterly, 19(4), 485-510. doi:10.1177/004208168401900406.

31. Klimas, P., Czakon, W. (2010). Sieci oraz firmy kotwice - ich znaczenie $w$ gospodarce opartej na wiedzy, In Zarzadzanie i informatyka. Dylematy $i$ kierunki rozwoju, Katowice.

32. Kondalkar, V. G. (2010). Organization Effectiveness and Change Management. PHI Learning Pvt. Ltd.

33. Kotarbiński, T. (1982) Traktat o dobrej robocie. Wrocław-Warszawa- Kraków-Gdańsk-Łódź: Ossolineum.

34. Kozak, A. (2017). Czy koprodukcję ustug publicznych można traktować jako innowacje społeczna?? Humanum. Międzynarodowe Studia Społeczno-Humanistyczne, 26(3), 73-85.

35. Kożuch, B. (2004). Zarzadzanie publiczne. Warszawa: Placet.

36. Kożuch, B. (2011). Skuteczne współdziałanie organizacji publicznych $i$ pozarzadowych. Monografie i Studia Instytutu Spraw Publicznych Instytutu Jagiellońskiego, Kraków.

37. Kożuch, B., Sienkiewicz-Małyjurek, K. (2016). Key factors of inter-organisational collaboration in the public sector and their strength. International Journal of Contemporary Management, 15(3), 123144.

38. Latusek, D. (2008). Trustworthiness as an Impression. In D. Jemielniak (Ed.), Management Practices in High-Tech Environments (pp. 152166). Hershey - New York: Information Science Reference.

39. Latusek, D., Cook, K. S. (2012). Trust in Transitions. KYKLOS, 65(4).

40. Latusek-Jurczak, D., Prystupa-Rzadca, K. (2014). Collaboration and trust-building in open innovation community. Jorunal of Economics \& Management, University of Economics in Katowice, 17.

41. Lewis, C., Fall, F. (2017). Enhancing public sector efficiency and effectiveness in the Czech Republic. 
The effectiveness of the public services co-production process - results of a systematic literature review

OECD Economics Department Working Papers, 1363, Paris: OECD Publishing.

42. Lino, A. F., Aquino, A. C. B. D., Azevedo, R. R. D., \& Brumatti, L. M. (2019). From rules to collaborative practice: When regulatory mechanisms drive collective co-production. Public Money \& Management, 39(4), 280-289. doi: 10.1080/ 09540962.2019.1592909

43. Loeffler, E., \& Bovaird, T. (2016). User and Community Co-Production of Public Services: What Does the Evidence Tell Us? International Journal of Public Administration, 39(13), 10061019. doi: 10.1080/01900692.2016.1250559

44. Mandl, U., Dierx, A., Ilzkovitz, F. (2008). The effectiveness and efficiency of public spending. European Economy. Economic Papers 301, European Commission.

45. Mangai, M. S., De Vries M. S. (2018), Coproduction as deep engagement.Improving and sustaining access to clean water in Ghana and Nigeria. International Journal of Public Sector Management, 31(1), 81-96.

46. Marschall, M. (2004). Citizen participation in the neighborhood context: a new look at co-production of local public goods. Political Research Quarterly, 57(2), 231-244.

47. Matei, A. I., Antonovici, C. G., \& Savulescu, C. (2016). Fostering Co-Public Marketing and CoProduction of Public Services in Romania. SSRN Electronic Journal. doi: 10.2139/ssrn.2939506

48. McQuaid, R. W. (2010). Theory of Organizational Partnerships: Partnership Advantages, Disadvantages and Success Factors, In S. P. Osborne (ed.), The New Public Governance: Emerging Perspectives on the Practice of Public Governance (pp. 130-147). New York: Routledge.

49. Meijer, A. (2012). Co-Production in an Information Age: Individual and Community Engagement Supported by New Media. Voluntas, 239(4), 11561172.

50. Mihaiu, D. M., Opreana, A., Cristescu, M. P. (2010). Efficiency, Effectiveness and Performance of the Public Sector. Journal for Economic Forecasting, Institute for Economic Forecasting, 0(4), 132-147.

51. Miller, C., Stirling, S. (2004). Co-production in Children's Services. London: Office of Public Management.

52. Mitlin, D. (2008). With and Beyond the State - CoProduction as a Route to Political Influence, Power, Transformation for Grassroots Organizations. Environment and Urbanization, 20(2), 339-360.

53. Moore, M. (1995). Creating public value: Strategic management in government. Cambridge, MA: Harvard University Press.
54. Musso, J. A., Young, M. M., Thom, M. (2018). Volunteerism as co-production in public service management: application to public safety in California. Public Management Review, 21(4), 473-494. doi: 10.1080/14719037.2018.1487574

55. Needham, C. (2008). Realising the Potential of Coproduction: Negotiating Improvements in Public Services. Social Policy \& Society, 7(2), 221-231.

56. OECD (2011), Together for Better Public Services. Partnering with Citizens and Civil Society, OECD Public Governance Reviews, OECD Publishing.

57. Osborne S., Brown K. (2005), Managaing Change and Innovation in Public Service Organizations. London: Routlege.

58. Osborne S.P. (ed.) (2010), The New Public Governance? Emerging Perspectives on the Theory and Practice of Public Governance. London/New York: Routledge.

59. Osborne, S. P., McLaughin, K., Chew, C. (2010). Relationship marketing, relational capital and the governance of public services delivery. In $S$. P. Osborne S. P. (ed.), The New Public Governance: Emerging Perspectives on the Theory and Practice of Public Governance. New York: Routledge.

60. Osborne, S., Strokosch, K. (2013). It takes two to tango? Understanding the co-production of public services by integrating the services management and public administration perspectives, British Journal of Management, 24, 31-47.

61. Osborne P., Radnor Z., Strokosch K. (2016), Coproduction and the co-creation of value in public services: A suitable case for treatment? Public Management Review, 18(5), 639-653.

62. Ostrom V., Ostrom E. (1977) Public Goods and Public Choices. In E. S. Savas (Ed.), Alternatives for Delivering Public Services. Toward Improved Performance (pp. 7-49). Boulder: Westview Press.

63. Ostrom, E. (1990). Governing the commons. The evolution of institutions for collective action. Cambridge: Cambridge University Press.

64. Ostrom, E. (1996), Crossing the great divide: coproduction, synergy and development, World Development, 24(6), 1073-1087.

65. Oxford Dictionary of English (2010), Oxford University Press.

66. Palumbo, R. (2016). Contextualizing co-production of health care: a systematic literature review. International Journal of Public Sector Management, 29(1), 72-90. doi: 10.1108/ijpsm-072015-0125

67. Panda, D. K. (2016). Public private partnerships and value creation: the role of relationship dynamics, International Journal of Organizational Analysis, 24(1), 162-183. 


\section{A. Kozak}

68. Paskaleva, K., \& Cooper, I. (2018). Open innovation and the evaluation of internet-enabled public services in smart cities. Technovation, 78, 414. doi: 10.1016/j.technovation.2018.07.003

69. Pestoff, V., Osborne, S. P., Brandsen, T. (2006). Patterns of co-production in public services. Some concluding thoughts. Public Management Review, 8(4), 591-595.

70. Pestoff, V. (2011), Co-production, new public governance and third sector social services in Europe, Ciências Sociais Unisinos, 47(1), 15-24.

71. Pestoff, V. (2012), Co-production and Third Sector Social Services in Europe: Some Concepts and Evidence. Voluntas, 23, 1102-1118.

72. Pestoff, V., Brandsen, T., Verschuere, B. (2012), New public governance, the third sector and coproduction. New York/London: Routledge.

73. Pollitt, Ch., Bouckaert, G. (2004), Public Management Reform. A Comparative Analysis, Second Edition. New York: Oxford University Press Inc.

74. Poochaoren, O., Ting, B. (2015), Collaboration, Coproduction, Networks - Convergence of Theories, Public Management Review, 17(4), 587-614.

75. Przywojska, J. (2014). Nowe zarzadzanie $i$ governance $w$ pracy socjalnej, Warszawa: Nowa Praca Socjalna, Centrum Rozwoju Zasobów Ludzkich.

76. Radnor, Z., Osborne, S. P., Kinder, T., Mutton, J. (2014). Operationalizing co-production in public service delivery. The contribution of service blueprinting. Public Management Review, 16(3).

77. Sicilia M. Guarini E., Sancino A., Andreani M. (2016), Ruffini R., Public services management and co-production in multi-level governance settings, "International Review of Administrative Science, Vol. 82(1), p. 8-27.

78. Sicilia, M., Guarini, E., Sancino, A., Andreani, M., \& Ruffini, R. (2015). Public services management and coproduction in multi-level governance settings. International Review of Administrative Sciences, 82(1), 8-27. doi: 10.1177/0020852314566008

79. Sienkiewicz-Małyjurek K., (2016). Innowacyjność koprodukcji w zarzadzaniu publicznym na poziomie lokalnym. Organizacja $i$ Zarzadzanie. Zeszyty Naukowe Politechniki Śląskiej, 89, 421-435.

80. Sorensen, E., Trofing, J. (2011). Enhancing Collaborative Innovation in the Public Sector, Administration \& Society, 43(8), 842-868.

Steele, J., Iliinsky, N. (2010). Beautiful Visualization. Looking at Data through the Eyes of Experts (Chapter 3: Wordle). O'Reilly Media.
82. Stewart, J. (2009). The dilemmas of engagement: the role of consultation in governance. Canberra: ANU E-Press. Retrieved from http://pressfiles.anu.edu.au/downloads/press/p102721/pdf/boo k.pdf? referer $=176$

83. Sztompka, P. (2007), Zaufanie. Fundament społeczeństwa. Kraków: Znak.

84. Roberts, A., et al. Treat Me Right, Treat Me Equal: Using National Policy and Legislation to Create Positive Changes in Local Health Services for People with Intellectual Disabilities. Journal of Applied Research in Intellectual Disabilities, 26(1), 14-25., doi:10.1111/jar.12009.

85. Tranfield, D., Denyer, D., and Smart, P. (2003), Towards a methodology for developing evidenceinformed management knowledge by means of systematic review. British Journal of Management, 14, 3, p. 207.

86. Tuurnas, S. (2015). Learning to co-produce? The perspective of public service professionals. International Journal of Public Sector Management, 28(7), 583-598.

87. Wiewiora, A., Keast, R., \& Brown, K. (2015). Opportunities and Challenges in Engaging Citizens in the Co-Production of Infrastructure-Based Public Services in Australia. Public Management Review, 18(4), 483-507. doi: 10.1080/ 14719037.2014.999820

88. Wilkin, J. (2013). Kategoria jakości rządzenia $w$ naukach spolecznych - zagadnienia metodologiczne. In J. Wilkin (ed.) Jakość rządzenia w Polsce. Jak ja badać, monitorować i poprawiać? Warszawa: Wydawnictwo Naukowe Scholar.

89. Wolfl A. (2005), The service economy in OECD country. In OECD, Enhancing the Performance of the Services Sector (pp. 27-61). OECD Publishing.

90. Van de Walle S.G.J, Scott Z. (2009), The role of public services in state- and nation building: Exploring lessons from European history for fragile states. Governance and Social Development Resource Centre, University of Birmingham.

91. Verschuere, B., Brandsen, T., \& Pestoff, V. (2012). Co-production: The State of the Art in Research and the Future Agenda. VOLUNTAS: International Journal of Voluntary and Nonprofit Organizations, 23(4), 1083-1101. doi: 10.1007/s11266-012-9307-8

92. Yang, K. (2006). Trust and citizen involvement decisions. Trust in citizens, trust in institutions, and propensity to trust. Administration \& Society, 38(5).

93. Zakrzewska-Bielawska, A. (2016). Ambidexterity światowe trendy eksploracji $w$ naukach o zarzadzaniu. Przeglad Organizacji, 1, 16-23.

94. Zieleniewski, J. (1969). Organizacja i zarzadzanie. Warszawa: PWN. 